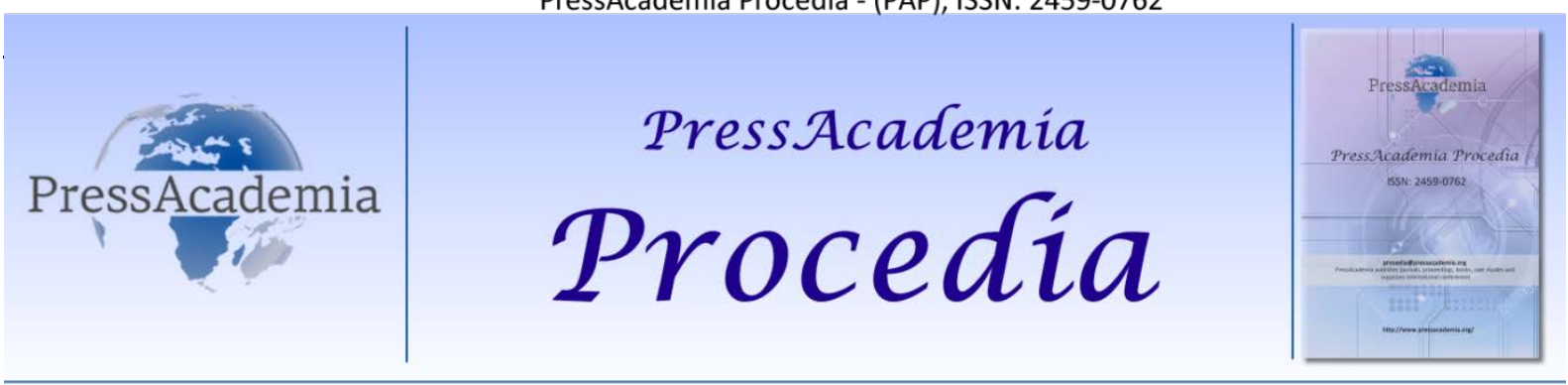

Global Business Research Congress (GBRC), May 26-27, 2016, Istanbul, Turkey.

\title{
A RESEARCH FOR CORPORATE SOCIAL RESPONSIBILITY PERCEPTION OF ACCOUNTING PROFESSIONALS: THE CASE OF TRABZON
}

\section{DOI: 10.17261/Pressacademia.2016118624}

\author{
Erol Tekin ${ }^{1}$, Yasar Bayraktar ${ }^{2}$ \\ ${ }^{1}$ Karadeniz Technical University, erolktu@gmail.com \\ ${ }^{2}$ Karadeniz Technical University, yasarbayraktar@ktu.edu.tr
}

\begin{abstract}
The purpose of this study is to determine the perceptions of CSR activities and the factors that have influence on it. In this regard, a research was carried out in Trabzon to examine the accounting professionals' CSR perception whether it changes in terms of factors such as gender, age, education skill, CSR training, abroad experience and tenure. Questionnaire technique was used for data collection method in the study. The collected data were analyzed with t-test and ANOVA test by using SPSS. The research results indicate that accounting professionals have high CSR perception as expected. In addition, according to test results related to social responsibility dimensions, economic responsibility dimension has no significant differences in terms of any factors and legal responsibility dimension has only a significant difference in terms of abroad experience. On the other hand, while ethical responsibility dimension has significant difference in terms of CSR training, philanthropic responsibility has significant difference in terms of tenure and age.
\end{abstract}

Keywords: Corporate social responsibility (CSR), accounting professionals, CSR perception.

JEL Codes: M10, M14, M41

\section{INTRODUCTION}

Nowadays, the social responsibility concept has become more important than ever. Because of based upon the customers' expectations in modern times, businesses have started to give importance to social responsibility in order to create an image of more sensitive to environment and social welfare besides profit maximization. In fact businesses with all its shareholders and stakeholders feel responsibility towards society and environment within the framework of corporate social responsibility. The financial situation of businesses is important in the fulfillment of these responsibilities. The fair presentation and faithful representation of financial statements which are as indicators of financial situation are the responsibility of accounting professionals. The professionals are obliged to protect the interests of all interest groups within the framework of impartiality, transparency, accountability and reliability. Thus, accounting and accounting professionals can contribute CSR's economic, legal, ethical and philanthropic responsibilities dimensions. On the other hand, according to the Application Serial No:1 General Communiqué on Accounting System Application, the concept of social responsibility is expressed as the necessity to protect the interests of all segments of society rather than some certain individuals or groups while applying accounting transactions in an accounting organization such as preparation and presentation of financial statements, and therefore to act in a realistic, objective, transparent and honest way in the course of knowledge production. In this respect, accounting professionals undertake important roles in the fulfillment of corporate social responsibility. Thereby it is expected from accounting professionals to have sense of responsibility and high CSR perception. 
In this study, it is attempted to determine accounting professionals' perception on CSR activities and the factors that have influence on it. Primarily, the concept of CSR and the relationship between CSR and accounting is addressed. After then 113 accounting professionals' CSR perceptions that work in Trabzon are evaluated and results of research are given in the methodology part. Furthermore, corporate social responsibility perception is examined in terms of CSR training and abroad experience factors unlike similar studies in the literature. Thus, the CSR concept's perception level that coincide with accounting science have been identified in terms of professionals and the factors that have influence on CSR dimensions have been revealed.

\section{LITERATURE REVIEW}

Corporate Social Responsibility is a concept that has begun to be heard since 1970s. This concept has reached till today defined in different ways by different authors. The first definition of CSR has been revealed by Bowen (1953) within the framework of "The Social Responsibility of Business Men". According to Bowen (1953), social responsibility is that managers comply with both the objectives of the business and society's expectations and values, implement by setting policies that is consistent with these expectations and values, make decisions and implement the activities. Afterwards, Researchers such as Friedman, Davis, Stone, Carroll and Frederick have also addressed the social responsibility concept in the framework of not only business men's social responsibility but also businesses' corporate social responsibility. Davis (1960) stated that it is business decisions were taken at a higher than the economic interests and the behavior displayed. Friedman (1970) stated as fulfilling only the businesses' economic responsibilities by defining the CSR concept within the legal boundaries. Afterwards, Researchers such as Davis (1973), Stone (1975), Carroll (1979) and Frederick (1987) stated that businesses have not only economic and legal responsibilities but also they have different responsibilities to other stakeholders (McGee, 1998: 378). In this context, CSR concept refers to all internal and external stakeholders. Wood (1990:86) has classified them on the basis of primary and secondary stakeholders.

According to Wood (1990), primary stakeholders consist of employees, customers, suppliers, rivals and shareholders. Secondary stakeholders are nature-environment, government and society. Businesses are responsible for both stakeholder groups. Also new stakeholders have been added into business' stakeholders concepts over the time. These can be expressed as financial sector, media, waqfs and associations, NGOs, foreign governments, investors and environmental activists. In addition to this, Carroll (1979) stated that social responsibility has four dimensions namely economic, legal, ethical, and philanthropic (Aktan and Börü, 2006: 56-57; Düren, 2002: 196-197).

Accounting has often been called the "language of business". It is the art of measuring, describing and interpreting economic activities of a business. Financial information about a business is needed by many outsiders. So the goal of the accounting is to provide useful information to decision makers such as investors, employees, customers, suppliers, universities, government and etc. Thus accounting is the connecting link between decision makers and business operations. Furthermore accountability is crucial in our era that we live in. So accounting function is not only important for owners of a business but also important for stakeholders who care about the financial situation of a business (Meigs and Meigs, 1990: 4-5).

According to the Application Serial No:1 General Communiqué on Accounting System Application, the concept of social responsibility that has the characteristic of accounting constitution, refers to the responsibility of accounting for performing its function, and indicates the extent, content, place and purpose of accounting. This responsibility is expressed as the necessity to protect the interests of all segments of society rather than some certain individuals or groups while applying accounting transactions in an accounting organization such as preparation and presentation of financial statements, analysis and interpretation of results. Therefore, financial information is required to be presented in a realistic, objective, timely, transparent and honest way. In this respect, it can be stated that accounting's social responsibility concept and CSR concept have similar basic foundation. Indeed, Daştan and Bellikli (2015:186) explained these similarities as shown in Figure 1. 
Figure 1: Corporate Social Responsibility and Accounting Relationship

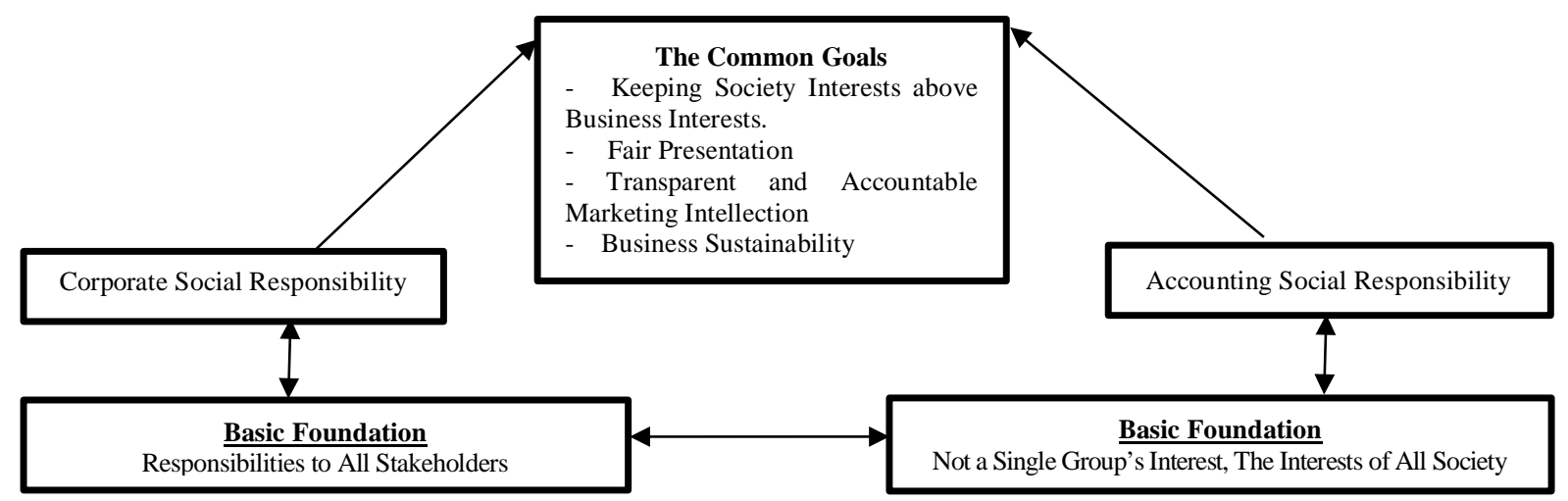

As seen in Figure 1, both concepts focus on interests groups which are related to society and business. In this regard, looking out for society's interest rather than business' interest, transparency and accountability of financial reporting are the focal point of both concepts. In addition, reporting of business activities related to corporate social responsibility is made thanks to accounting. In this respect, there is a tendency from traditional accounting to social accounting. Traditional accounting has only focused on businesses' own operations and ignored external environment. Social accounting approach acts to be aware of responsibilities towards society in a transparent and accountable setting. Therefore, businesses must act within the framework of corporate social responsibility to sustain their existence (Daştan and Bellikli, 2015: 186). In this context, it is seen that accounting is directly related to four dimensions of corporate social responsibility. Also in literature, several studies which indicate the relationship between accounting and CSR are as follows:

Özkol et all (2005) assess the relationship between CSR and accounting in terms of CSR dimensions. They emphasized the social responsibility and sustainable development in order to explain the importance and position of this concept on accounting profession besides focusing on professionals' role in protecting the whole stakeholders' interests. In addition, Kaya (2008), states that individual's CSR perceptions do not vary based on their gender and their working in public sector and private sector. But it differs depending on their age at moderate level and education at higher level. Erkman ve Şahinoğlu (2012) focused on employee's perception of CSR and their commitment to their organization. Study shows that employee's comprehension of CSR has positive and significant relationship with organizational commitment. Furthermore Demir (2013) emphasize that accounting professionals must be conscious about their social responsibilities in presenting financial information to stakeholders. Köroğlu and Ersöz (2015) found that in terms of professionals, there is relationship between reliability and accuracy of accounting information and CSR's legal and ethical dimensions. Also tenure and numbers of taxpayers affect the perception of CSR' legal and ethical dimensions. As seen in literature, there is clearly relationship between accounting profession and CSR.

\section{DATA AND METHODOLOGY}

Accounting has the same basic foundation with the concept of CSR. Therefore, accounting is a field which is in relation with CSR's four dimension and contributes to them. Thus accounting professionals' perception on corporate social responsibility becomes important. Because they are professionals who reflect the contribution of accounting science in implementing economic, legal, ethical and philanthropic responsibilities. Businesses will be able to fulfill CSR activities how much professionals' CSR perception is high.

In this respect, it is attempted to determine accounting professionals' perception on CSR activities and the factors that have influence on it. In this regard, a research was carried out in Trabzon to examine the accounting professionals' CSR perception whether it changes in terms of factors such as gender, age, education skill, CSR training, abroad experience and tenure. 
In this context, the factors that affect the accounting professionals' CSR perception were determined within the framework of Carroll (1979) who set out the CSR's economic, legal, ethical and philanthropic responsibilities. Research model in Figure 2 has been created in the scope of study.

Figure 2. Research Model

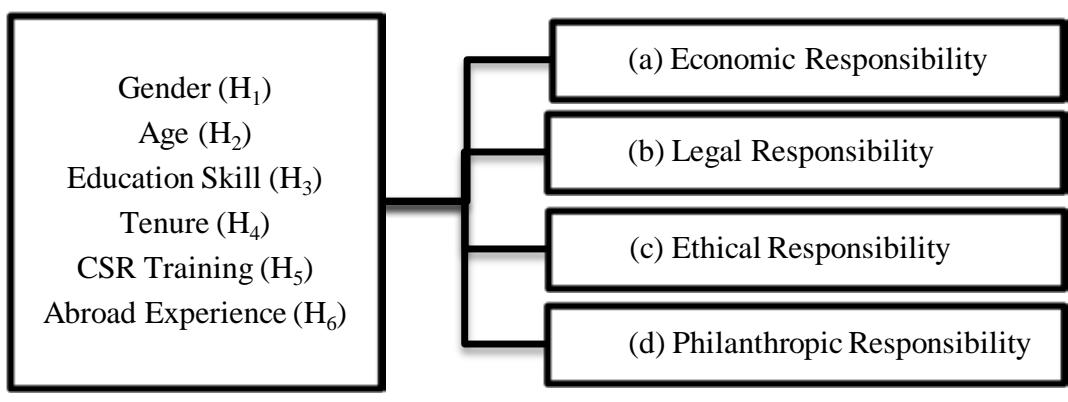

Within the framework of this model, the hypotheses of study are as follows:

$\mathbf{H}_{1 \mathrm{a} / \mathrm{b} / \mathrm{c} / \mathrm{d}}$ : According to the gender variable, there is a significant difference between accounting professionals' perception towards CSR' dimensions (economic, legal, ethical and philanthropic responsibility).

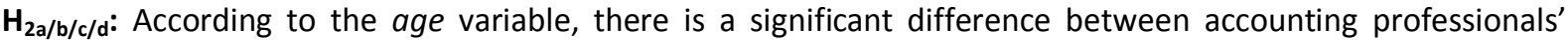
perception towards CSR' dimensions (economic, legal, ethical and philanthropic responsibility).

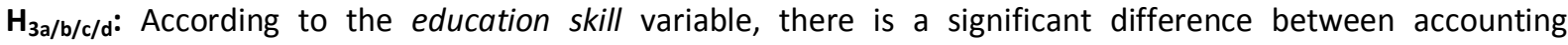
professionals' perception towards CSR' dimensions (economic, legal, ethical and philanthropic responsibility).

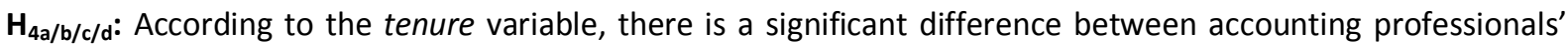
perception towards CSR' dimensions (economic, legal, ethical and philanthropic responsibility).

$\mathbf{H}_{5 \mathrm{a} / \mathrm{b} / \mathrm{c} / \mathrm{d}}$ : According to the CSR training variable, there is a significant difference between accounting professionals' perception towards CSR' dimensions (economic, legal, ethical and philanthropic responsibility).

$\mathbf{H}_{6 \mathrm{a} / \mathrm{b} / \mathrm{c} / \mathrm{d}}$ : According to the abroad experience variable, there is a significant difference between accounting professionals' perception towards CSR' dimensions (economic, legal, ethical and philanthropic responsibility).

Questionnaire technique has been used for data collection in the study. The first part of questionnaire consists of questions regarding demographic features. The second part consists of questions regarding economic, legal, ethical and philanthropic responsibilities in order to measure the CSR perception.

In this study, the CSR scale developed by Maignan (2001) which comprise four dimensions was used by adapting for Turkey. The scale to measure CSR dimensions consists of four questions for each and totally sixteen questions. The obtained data were analyzed with statistical package named SPSS statistics 20.0 for Windows. In this regard, t- Test was used for analyzing the variables that are consisted of two groups such as gender, CSR training and abroad experience. ANOVA test was used for analyzing the variables that are consisted of more than two variables such as tenure, age and education skill.

\section{FINDINGS AND DISCUSSIONS}

In this study, according to $\mathrm{KMO}$ and Bartlett test for testing the suitability for factor analysis of research data; KMO value: 0,824 and Bartlett test: 925.828 ( $p=0.000)$ were found significant. When considering the results of CSR's dimensions and scale's reliability analysis; the reliability of dimensions respectively is as follows: economic dimension 67,8 \% legal dimension 87,5 \% ethical dimension 88,7\% and philanthropic dimension $72,8 \%$. According to the results of scale's reliability; questionnaire's reliability coefficient (Cronbach Alpha) was found $87,9 \%$. It is the value that is acceptable between $80-100 \%$ confidence interval. Therefore, it can be stated that the scale is highly reliable and it can be safely used in making scientific judgment or society surveys (Kalaycı, 2014: 405). 
Table 1: Demographic Features of Participants Related to Percent and Frequency Distributions

\begin{tabular}{|c|c|c|c|}
\hline Variables & Groups & Frequency (f) & Percent (\%) \\
\hline \multirow[b]{2}{*}{ Gender } & Female & 22 & 19,5 \\
\hline & Male & 91 & 80,5 \\
\hline \multirow{5}{*}{ Age } & Under 30 & 30 & 26,5 \\
\hline & $31-40$ & 35 & 31,0 \\
\hline & $41-50$ & 24 & 21,2 \\
\hline & $51-60$ & 18 & 15,9 \\
\hline & Over 60 & 6 & 5,3 \\
\hline \multirow{4}{*}{ Education Skill } & High School & 12 & 10,6 \\
\hline & Undergraduate & 8 & 7,1 \\
\hline & Bachelor's Degree & 89 & 78,8 \\
\hline & Postgraduate & 4 & 3,5 \\
\hline \multirow{4}{*}{ Tenure } & Less than 5 years & 26 & 23,0 \\
\hline & $5-10$ years & 26 & 23,0 \\
\hline & $11-15$ years & 13 & 11,5 \\
\hline & More than 15 years & 48 & 42,5 \\
\hline \multirow{2}{*}{ CSR Training } & Yes & 39 & 34,5 \\
\hline & No & 74 & 65,5 \\
\hline \multirow{2}{*}{ Abroad Experience } & Yes & 21 & 18,6 \\
\hline & No & 92 & 81,4 \\
\hline \multicolumn{2}{|c|}{ Total } & $n=113$ & $\% 100$ \\
\hline
\end{tabular}

Table 1 shows the demographic features of participants related to percent and frequency distributions. According to Table 1, gender of the accounting professionals who participate the survey, consists of $19,5 \%$ female and $80,5 \%$ male. According to accounting professionals' age variable, participants are $26,5 \%$ under the age of $30,31 \%$ between $31-40,21,2 \% 41-50,15,9 \% 51-60$ and 5,3\% over 60 . Education skills of participants are $10,6 \%$ high school, 7,1\% undergraduate, 78,8\% Bachelor's degree and only 3,5\% postgraduate. Tenure of participants are 23\% less than 5 years, 23\% 5-10 years, 11,5\% 11-15 years and 42,5\% more than 15 years.

In addition, it is asked whether participants have training related to corporate social responsibility besides the demographic features. According to responses, it is determined that more than half of the accounting professionals $(65,5 \%)$ haven't take CSR training. Participants who have taken training, are $34,5 \%$. When considering the responses related to abroad experience, $81,4 \%$ of them have abroad experience and $18,6 \%$ of them haven't been in abroad.

Table 2: Accounting Professionals' Corporate Social Responsibility Perception Levels

\begin{tabular}{|l|c|c|c|}
\hline CSR Dimensions & $\mathbf{N}$ & Average & Standard Deviation \\
\hline Economic CSR & 113 & 3,5575 &, 71885 \\
\hline Legal CSR & 113 & 4,5243 &, 71415 \\
\hline Ethical CSR & 113 & 4,3097 &, 78794 \\
\hline Philanthropic CSR & 113 & 3,7699 &, 71874 \\
\hline
\end{tabular}

Table 2 shows the average and standard deviation of accounting professionals' perception level. When examining the accounting professionals' scores that they receive from corporate social responsibility scale (Table 2), they highly evaluate the legal responsibility $(4,52)$ in CSR dimensions. It shows that accounting 
professionals' CSR legal perception is quite high. Legal responsibility dimension is followed respectively by ethical $(4,30)$, philanthropic $(3,76)$ and economic $(3,55)$ dimensions. The total average of accounting professionals' CSR perception is 4,04.

Table 3: Hypothesis Tests Regarding Accounting Professionals' CSR Perception

\begin{tabular}{|c|c|c|c|c|c|c|c|c|c|}
\hline \multirow{2}{*}{ Variables } & \multirow{2}{*}{$\begin{array}{c}\text { CSR Dimensions } \\
\text { Groups }\end{array}$} & \multicolumn{2}{|c|}{$\begin{array}{c}\text { (a) } \\
\text { Economic }\end{array}$} & \multicolumn{2}{|c|}{$\begin{array}{l}\text { (b) } \\
\text { Legal }\end{array}$} & \multicolumn{2}{|c|}{$\begin{array}{c}\text { (c) } \\
\text { Ethical }\end{array}$} & \multicolumn{2}{|c|}{$\begin{array}{c}\text { (d) } \\
\text { Philanthrophic }\end{array}$} \\
\hline & & $t / F$ & $\mathbf{p}$ & $t / F$ & p & $t / F$ & $\mathbf{p}$ & $t / F$ & $\mathbf{p}$ \\
\hline \multirow{2}{*}{ Gender $\left(\mathbf{H}_{1}\right)$} & Female & \multirow{2}{*}{1,416} & \multirow{2}{*}{ 160 } & \multirow{2}{*}{1,432} & \multirow{2}{*}{ 155 } & \multirow{2}{*}{ 967 } & \multirow{2}{*}{ 343 } & \multirow{2}{*}{1,104} & \multirow{2}{*}{ 272 } \\
\hline & Male & & & & & & & & \\
\hline \multirow{5}{*}{ Age $\left(\mathbf{H}_{\mathbf{2}}\right)$} & Under 30 & \multirow{5}{*}{1,635} & \multirow{5}{*}{ 171 } & \multirow{5}{*}{1,208} & \multirow{5}{*}{,312 } & \multirow{5}{*}{,537 } & \multirow{5}{*}{ 709 } & \multirow{5}{*}{3,983} & \multirow{5}{*}{$\underline{005}$} \\
\hline & $31-40$ & & & & & & & & \\
\hline & $41-50$ & & & & & & & & \\
\hline & $51-60$ & & & & & & & & \\
\hline & Over 60 & & & & & & & & \\
\hline \multirow{4}{*}{ Education Skill $\left(\mathbf{H}_{3}\right)$} & High School & \multirow{4}{*}{,511 } & \multirow{4}{*}{ 675 } & \multirow{4}{*}{,429 } & \multirow{4}{*}{ 733 } & \multirow{4}{*}{ 603 } & \multirow{4}{*}{614} & \multirow{4}{*}{ 709 } & \multirow{4}{*}{,549 } \\
\hline & Undergraduate & & & & & & & & \\
\hline & Bachelor's Degree & & & & & & & & \\
\hline & Postgraduate & & & & & & & & \\
\hline \multirow{4}{*}{ Tenure $\left(\mathbf{H}_{4}\right)$} & Less than 5 years & & & & & & & & \\
\hline & $5-10$ years & 057 & 016 & 1501 & 100 & $760+2-3$ & 517 & 1221 & 005 \\
\hline & $11-15$ years & או & , 416 & 1,581 & , 198 & , /64 & וא & 4,334 &, 000 \\
\hline & More than 15 years & & & & & & & & \\
\hline CSP Training (H) & Yes & & 218 & 1025 & 308 & 2015 & 020 & 1221 & 225 \\
\hline CSK ITdIIIIS $\left(\cap_{5}\right)$ & No & 1,240 & 218 & $1,0<5$ & , 308 & $-2,215$ &, 029 & $1,2 \angle 1$ & ,2L5 \\
\hline & Yes & (200 & 250 & & & & & & \\
\hline Abroad Experlence & No &,- 939 & 350 & $-2, \mathrm{U}$ / &, 042 &,- 919 & ,360 & $-1, \mathbf{U} 8$ & , 2/9 \\
\hline
\end{tabular}

ANOVA and t-Test analysis are used to test the research hypotheses. Table 3 shows the results of $t$ - Test which is used for analyzing the variables that are consisted of two groups such as gender, CSR training and abroad experience and ANOVA test is used for analyzing the variables that are consisted of more than two variables such as tenure, age and education skill.

Table 3 shows that when examining differences by several variables, the perceptions related to economic responsibilities any variables have no significant difference. In this context, $\boldsymbol{H}_{\mathbf{1 a}}-\boldsymbol{H}_{\mathbf{2 a}}-\boldsymbol{H}_{\mathbf{3 a}}-\boldsymbol{H}_{\mathbf{4 a}}-\boldsymbol{H}_{5 a}$ and $\boldsymbol{H}_{6 a}$ hypotheses are rejected. This result is similar to Bir et all (2014: 2316) "gender" and Köroğlu and Ersöz (2015: 143) "age, education skill, tenure" in literature.

When examining differences by several variables the perceptions related to legal responsibilities, it appears that only abroad experience variable has significant difference in CSR perception of accounting professionals. In this context, $\boldsymbol{H}_{\boldsymbol{6} \boldsymbol{b}}$ hypothesis is accepted.

When examining differences by several variables the perceptions related to ethical responsibilities, it appears that only CSR training variable has significant difference in CSR perception of accounting professionals. In this context, $\boldsymbol{H}_{\mathbf{5} \boldsymbol{c}}$ hypothesis is accepted.

When examining differences by several variables the perceptions related to philanthropic responsibilities, it appears that only tenure and age variables have significant difference in CSR perception of accounting professionals. In this context, $\boldsymbol{H}_{\mathbf{2} \boldsymbol{d}}$ and $\boldsymbol{H}_{\mathbf{4} \boldsymbol{d}}$ hypotheses are accepted. 


\section{CONCLUSION}

Accounting professionals undertake quite important roles in presenting fair, honest, accurate and reliable information to the public and fulfilling social responsibility. To fulfill this responsibility relies on being conscious of social responsibility. Therefore, it is expected from accounting professionals to have high CSR perception. In this context, important findings have been found related to perceptions of CSR activities and the factors that have influence on it. CSR perception average is found 4,04 within the framework of professionals' economic, legal, ethical and philanthropic responsibilities. This average shows that CSR perception is quite high as expected according to the five point Likert scale.

It is found that factors such as gender, age, education skill, tenure, CSR training and abroad experience has no differences in accounting professionals' economic responsibility perception. In terms of legal responsibility, CSR perceptions of accounting professionals vary in abroad experience. This result shows that professionals, who have been in abroad, pay more attention to legal issues. Because there is some legal gaps in practice in Turkey and these can be filled easily by professionals whereas in abroad it is relatively more difficult. On the other hand, there is only significant difference in terms of CSR training variable in ethical responsibility. Such that, accounting professionals who have CSR training, ethical perception of them is quite high. This result shows the importance of training. Because, being knowledgeable with CSR can raise the awareness about protecting the interests of society. At this point, CSR knowledge is required to be gained with the help of training programs through the professional life as well as curriculum. Finally, there is significant difference in terms of age and tenure variables in philanthropic responsibility. This result shows that the professionals' tendency in charitable activities increase over time. This case is related to the understanding of economic performance is not only sufficient for sustainability. The tendency in the volunteer activities that response to the needs of society contributes to the increment of the value in the presence of society. Accounting professionals attribute more value to volunteer responsibilities owing to they acquire this awareness thanks to increasing age and tenure.

As a result, it can be said that professional training for accounting professionals and curriculum for students who will be accounting professionals in near future, need to be reconsidered in the context of CSR. In addition to this removing gap in the implementation of the laws and regulations in Turkey is important for both the credibility of profession and society welfare. On the other hand, promoting professionals in charitable activities is extremely important in terms of philanthropic responsibilities which are accepted as the most important dimension of CSR. All sorts of work to be done in increasing the accounting professionals' CSR perception are important for both professionals and society.

\section{REFERENCES}

Aktan, C.C and Börü, D. (2006), "Kurumsal Sosyal Sorumluluk Kavramı", İnternet Adresi: http://www.canaktan.org/yonetim/kurumsalsosyalsorum/kurumsal-sosyal/kurumsalsosyal.htm, Access Date: 01.04.2016.

Bir, Ç. S., Suher, i. K. and Altınbaşak, İ. (2014), "Kurumsal Sosyal Sorumluluk Yönelimi ve İşveren Çekiciliği", Journal of Yaşar University, 4 (15), pp. 2303-2326.

Bowen, H.R. (1953), "Social Responsibility of the Businessman", Harpers and Brothers: New York.

Carroll, A. B. (1979), “A Three-dimensional Conceptual Model of Corporate Social Performance”, Academy of Management Review, vol. 4, no. 4, pp. 497-505.

Daştan, A. and Bellikli, U. (2015), Kurumsal Sosyal Sorumluluk ve Muhasebe Etkileşimi: Türkiye'de Kurumsal Yönetim Endeksi'ne Dâhil İşletmelerde Bir Araştırma, Eskişehir Osmangazi Üniversitesi Iktisadi ve Idari Bilimler Dergisi, vol.10, pp.177-208.

Davis, K. (1960)," Can Business Afford to Ignore Social Responsibilities”, California Management Review, vol. 2, pp.70-76.

Davis, K. (1973), "The Case For and Against Business Assumption of Social Responsibilities", Academy of Management Journal, vol. 16, pp. 312-322.

Demir, B. (2013), “Kurumsal Sosyal Sorumluluk ve Muhasebe”, Eğitim ve Öğretim Araştırmaları Dergisi, 2(3), pp.225-233.

Düren, Z. (2002), “2000’li Yıllarda Yönetim”, Alfa Yayınları: İstanbul. 
Erkman, T. and Şahinoğlu, F. (2012), "Kurumsal Sosyal Sorumluluk Faaliyetlerine Illişkin Çalışan Algıları ile Örgütsel Bağlılı̆ın Hizmet Sektöründe İncelenmesi", Marmara Üniversitesi I..i.B. Dergisi, 33(2), pp.267-294.

Frederick, W.C. (1987), “Theories of Corporate Social Performance”. In Sethi, S.P. \& Falbe, C.M. (eds.), Business and Society. Lexington, MA: Lexington Books.

Friedman, M. (1970), "The Social Responsibility of Business is to Increase Its Profits", New York Times Magazine, vol. 13, pp. 32-33.

Kalaycı, Ş. (2014), "SPSS Uygulamalı Çok Değişkenli İstatistik Teknikleri”, edt. Ş. Kalaycı, Asil Yayın Dağııım: Ankara.

Kaya, H. (2008), "Demografik Özelliklerin Kurumsal Sosyal Sorumluluk Algılaması Üzerindeki Rolü: Bandırma Yerelinde Bir Araştırma", Balıkesir Üniversitesi Sosyal Bilimler Enstitüsü Dergisi, 11(20), pp.96-110.

Köroğlu, Ç. and Ersöz Ö. H. (2015), "Muhasebe Meslek Mensuplarının Bakış Açılarından Kurumsal Sosyal Sorumluluk Muhasebe ilişkisi”, Journal of Accounting, Finance and Auditing Studies, vol. 1, no. 3, 123-153.

Maignan, I. (2001), “Consumers' Perceptions of Corporate Social Responsibilities: A Cross-Cultural Comparison”, Journal of Business Ethics, vol. 30, pp. 57-72.

McGee, J. (1998), "Commentary on 'Corporate Strategies and Environmental Regulations: An Organizing Framework2 by A.M Rugman and A. Verbeke", Strategic Management Journal, vol. 19, no. 4, pp. 377-387.

Meigs, F. R. and Meigs, B.W. (1990), “Accounting: The Basis for Business Decisions”, Eighth Edition, Singapore: McGraw-Hill: 4-5.

Özkol, E., Çelik, M. and Gönen, S. (2005), "Kurumsal Sosyal Sorumluluk Kavramı ve Muhasebenin Sosyal Sorumluluğu”, Muhasebe ve Finansman Dergisi, Sayı 27, pp. 134-145.

Stone, C.D. (1975), "Where the Law Ends: The Social Control of Corporate Behavior", Harper and Row.

Wood, D. J. (1990), "Business and Society", Harper Collins Publishers: USA. 